\title{
IMPACT OF HVOTLS ON RESIDENTIAL PROPERTY RENTAL VALUES IN HIGH-BROW LAGOS METROPOLIS
}

*Akinjare, O. A., Oluwunmi, A. O. and Iroham, O. C. DOI: http://dx.doi.org/10.4314/ejesm.v5i1.7

Received $25^{\text {th }}$ December 2011; accepted $10^{\text {th }}$ February 2012

\begin{abstract}
High Voltage Overhead Transmission Lines (HVOTLS) otherwise refered to as power-lines have been debated to facilitate property value diminution. This current study investigates the impact of power-lines on the rents of residential properties in high brow Lagos. Questionnaires were distributed to registered Estate Surveying firms, residents within $200 \mathrm{~m}$ to power-lines in Surulere area of Lagos while an indepth interview of the Manager and field officers of the Akangba PHCN sub-station was conducted. On the average, a response rate of $66.5 \%$ was recorded. Findings revealed that residential property rents increased as distance from power-lines increased averagely by $=N=5,000.00$ and a mean value impact of $=N=786$ on neighbourhood rental value. The study encouraged the use of buried armour cables instead of overhead power-lines in future and the strict enforcement of ROWs within Lagos metropolis where power-lines already exist, in a bid to abate the effect of power line on property investments.
\end{abstract}

Keywords: HVOTLs, Power-line, Residential, Property, Rental Value, Surulere, Lagos and Metropolis.

\section{Introduction}

This study evaluates the impact of HVOTLs otherwise referred to as power lines on rental values within highbrow residential neighbourhoods in metropolitan Lagos.These power lines have been in Lagos metropolis from the British colonial era. The construction and commissioning of the first thermal electric power plant by Queen Elizabeth of England on Iddo Island in 1952 marked the beginning of the use of power lines in conveying electricity to consumers via sub stations on the immediate Island and other distant industrial and residential locations. These power lines were known to have traversed villages, remote settlements and lagoons within Lagos until rapid infrastructural development fostered by the oil boom of the early seventies, facilitated the amalgamation of these villages into metropolitan Lagos by the mid eighties. Also, Lagos, being the seat of power at the time of the Gen. Ibrahim Babangida led regime (1984-1993), experienced extensive land reclamation (still on till date) in order to accommodate more infrastructure. These brought the power lines to residential neighbourhoods. Moreover, human interactions with these lines have notably and

Department of Estate Management, School of Environmental Sciences, College of Science and Technology, P.M.B 1023,

Covenant University, Canaanland, Ota, Ogun State, Nigeria.

*Corresponding author Email:

lade.akinjare@covenantuniversity.edu.ng gradually climaxed into chaotic situations in notable parts of the state an country.

In recent times, the negativity associated with power line has fostered the need to investigate the true effect of power lines on the rent of residential properties in a bid to educate property investors on the pros and cons of investing in real estate within power line characterised neighbourhoods in metropolitan Lagos and Nigeria as a whole.

Numerous early studies such as those of Kinnard (1967), Wertheimer and Leeper (1979), Colwell and Foley (1979), Savitz et al (1988) and those of recent times such as Chalmers and Voorvaart (2009), have for long, sought to investigate both the impact of power lines on property values and its probable effect on the health of residents within close range and have concluded with varying degrees of findings as would be noted below.

Hamilton and Caruthers (1993) analysed a six year property market data. They found a diminution value of $5 \%$ on property proximal to power lines by 120 meters. Hamilton and Schwann (1995) surveyed 12,907 residential dwellings within four neighbourhoods in Vancouver, British Colombia within a period of 6 years (1985-1991). They reported a $6.3 \%$ diminution effect on 
properties located 100 meters to a $230 \mathrm{Kv}$ Power lines and a $1.1 \%$ diminution effect on properties 200 meters from another $500 \mathrm{Kv}$ Power lines. Complete removal of the pylon/power lines increased value by a $6.3 \%$ margin. Rosiers (1998), agreed with the findings of Colwell (1990) which portrayed a diminution in property values as a result of the visual effects of pylons and power lines. After a survey carried out on 507 single family sales, analysis showed a lesser diminution value on a property physically closer to a HVOTL but with its glare shielded by a wood, unlike other less proximal properties which had the direct glare of the power lines unshielded.

In Sims (1996), professionals in the real estate industry were subjected to a psychometric test anchored on assessing their perception regarding contaminated land. Results showed that overhead power cables were perceived to be of low risk. This differed from the study outcome of Slovic (1992) which indicated a greater perception of risk in this regard. According to Sims (2001), these studies enhanced media exposure on the issue of power-lines as they affect property values.

Des Rosiers (1998) studied the impact of highvoltage transmission lines on surrounding residential property values using a micro-spatial approach. The research was anchored on a sample of 507 single-family houses in the city of Brossard, Greater Montreal, Canada; 257 of these town cottages sold during the study period between February 1991 and November 1996. The study area comprised three distinct neighbourhoods ( $R, S$, and $T$ ) with a $315 \mathrm{kV}$ transmission power line traversing through the center. The data bank includes 25 residential property descriptors relating to physical, environmental, neighborhood, access, fiscal and sales time attributes, as well as a series of power line related descriptors. Standard and stepwise regression procedures were successively used in the analysis. The model showed that a residential property both adjacent to an HVTL easement and facing a pylon would experience a drop in value due to visual encumbrance by approximately $9.6 \%$ of the mean house price. Residences located 1 to 2 lots away from a pylon were found to usually benefit from a market premium due to increased visual clearance and privacy. This premium, on average is within the range of $7.4 \%$ and $9.2 \%$ of the mean house price. A property located directly beneath the power line would suffer a decrease in value because of low minimal clearance of the lines fostering visual obstruction. This decrease is lesser and averages about $4.7 \%$ of the mean home price. Residences with a moderate rear or side view on a power line structure but not adjacent to the easement usually experience a market premium of $2.8 \%$ to $3.8 \%$ due to the improved visual clearance these residential properties benefit from. The net visual encumbrance defined as the difference between proximity obstacles and advantages was found to reach its peak at about 50 to 100 meters away the easements' external boundary. It also diminished quickly and thereafter, entirely faded away 150 meters and beyond. Luxury home prices were also found to be more sensitive to the visual encumbrances of power line structures. However, the methodology of this in-depth study was based only on sales value and not the passing rent of residential properties. This current study initiates and facilitates the use of residential rental values in measuring power line effects.

Wolverton and Bottemiller (2003), an assenting study of an earlier research work by Cowger et al (1996). The study revealed that sales prices of properties are not momentously affected by the presence of a power line. Also, the data showed no discrepancy in appreciation rates between residences beside power line ROW and residences situated further away from the power line.

Lastly, Chalmers and Voorvaart (2009) also addressed the issue of power line impacts on residential property values and prices using a multiple regression framework. The authors investigated the influence of actual distance proximity and encumbrance on sales price and found proximity to have an insignificant effect on sales price. They concluded that "the only variable that appears to have any kind of systematic effect is the encumbrance variable," although its statistical significance varied and the effect was "generally small."

This current study identifies the paucity of Nigerian literature on this subject and seeks to not only compliment existing studies internationally but also to investigate the impact of power lines on the rents of residential properties in high brow Surulere in Lagos metropolis, Nigeria. 


\section{Study Area}

Lagos is located between latitudes $6^{\circ} 21^{\prime} \mathrm{N}$ and $6^{\circ} 34^{\prime} \mathrm{N}$ and longitudes $3^{\circ} 01^{\prime} \mathrm{E}$ and $3^{\circ} 27^{\prime} \mathrm{E}$, within the south western region of Nigeria and is bounded in the north and east by Ogun State, south by the Atlantic Ocean, west by Cotonou in Benin Republic.

Located on a total landed area of 3,345 sq km $(1,292 \mathrm{sq} \mathrm{mi})$ on four principal islands and adjacent parts of the Nigerian mainland, the islands are connected to each other and to the mainland by bridges. This represents $0.4 \%$ of Nigeria's territorial landmass (Esubiyi, 1994).
Major sections of the old city include Ebute-Metta, Yaba, Surulere, and Somolu, which now serve as the commercial district, on western Lagos Island; Ikoyi Island, situated just east of Lagos Island; Apapa, the chief port district, located on the mainland; residential Victoria Island; and industrialized Iddo Island. Importantly, mainland suburbs which formerly were part of the old western region were incorporated as part of the city in 1967. These areas included Agege, Ikeja, Alimosho, Alakuko etc. (Microsoft Encarta, 2007)

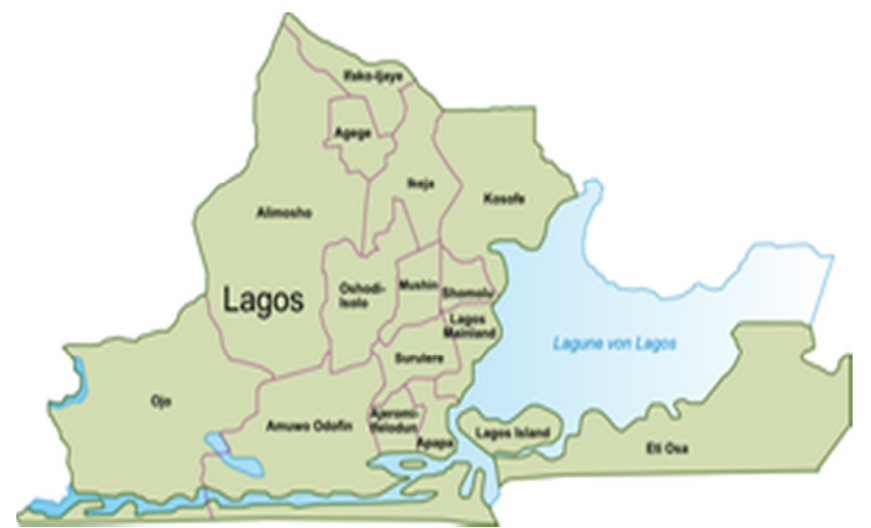

Figure 1 Map of Metropolitan Lagos.

Source: Lagos State Ministry of Information

Deductions from the result of the 2006 population census, indicates that Lagos state is believed to be the most populous state in Nigerian after Kano with a population of over 9 million people even though the result was refuted by the then Lagos State Governor who conducted a separate census exercise for the state resulting to a population about 14 million people (Sandra Yin, 2007).

Surulere, being the focus of this study, is one of the 20 Local Government Areas recognised by the Nigerian Constitution of 1999. Established in 1967 , it is located in the middle belt region of Lagos mainland and comprises both residential and commercial uses. Having a landed area of 23.0 kilometer square (Wikipedia, 2009), it inhabits 503,973 persons consisting of 261,256 males and 242,710 female residents National Population Census, (2006). Surulere Local Government Area has a population density of 21,912 persons per square kilometer confirming it as a densely populated area.

To the North, it is demarcated by Bishop Street and Obele-Oniwala in Mushin and Mainland Local Government areas. Continuing to the west, its boundary is demarcated by a Power Holding Company HVOTL on the other side of Jubril Martins through Masha to include all of Adelabu Street, old census office up to Babs Animashaun. Southernly, it is bound by Costain in Apapa Local Government Area and Ojo Local Government Area respectively. Towards Costain axis, it is bound by Abebe Village and Eric Moore. To the east, it is bound by an NRC (Nigerian Railway Corporation) railway crossing at Yaba (Mainland Local Government Area) but excludes the railway compound through the swamp at Alaska Estate (Lagos State Official website, 2009).

Surulere's good transportation/road network offers its residents easy accessibility to and fro 
most parts of the state. It interconnects the popular Victoria Island axis and the Central Business District of Ikeja en-route the Igammu Link bridge beside the National Theatre to Funsho Williams Avenue (formerly named as Western
Avenue) and Ikorodu road. Also, it is accessible to Oshodi area of the state via Ojuelegba and Mushin through the ever busy Agege motor road (Lagos State Official website, 2009).

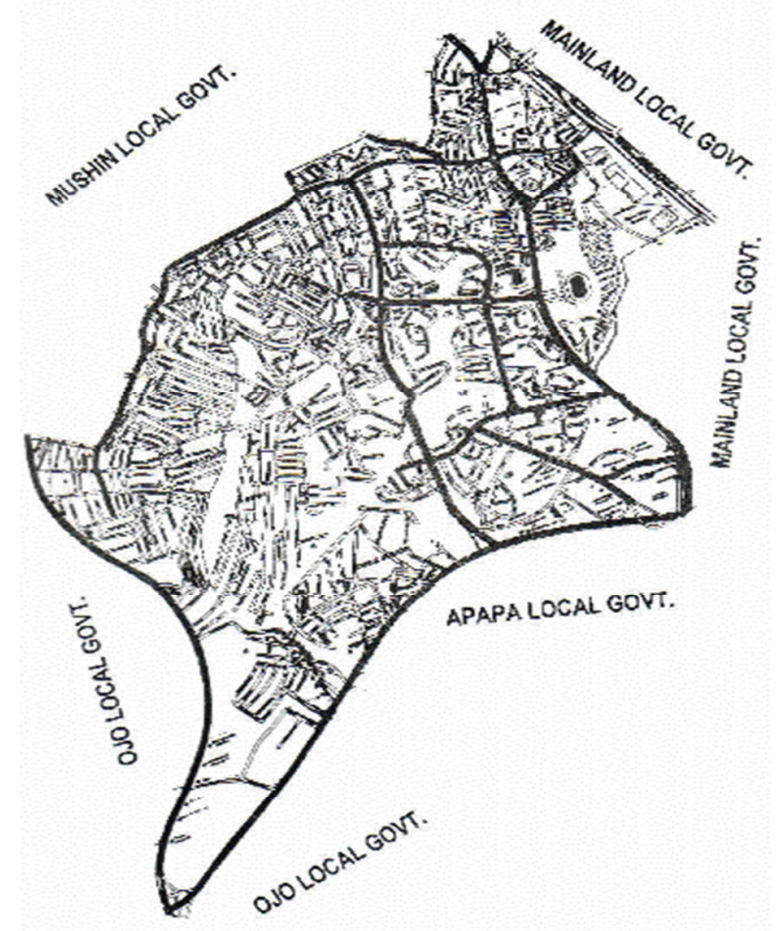

Figure 2 Map of Surulere Local Government Area showing its Boundaries Source: Lagos State Official Website.

\section{Methodology}

Primary data were collected through questionnaires distributed to Estate Surveyors and Valuers, residents within $200 \mathrm{~m}$ to power lines in Surulere area of Lagos State. The study sampled every other residential building along power line routes and within a $200 \mathrm{~m}$ perpendicular distance from the four power line routes totalling $31 \mathrm{~km}$ in Surulere axis. As shown in figure 3, these routes are namely: Akangba-Ojo $(11 \mathrm{~km})$, Akangba-Isolo $(7 \mathrm{~km})$, Akangba-Ijora $(5 \mathrm{~km})$ and Akangba-Apapa $(8 \mathrm{~km})$ routes.

Since the impact of power lines on the rents of nearby residential properties were not expected to be uniform as rents were presumed to increase with distance away from the power line, a four point distance range in the order of $0-50 \mathrm{~m}, 51$ $100 \mathrm{~m}, 101-150 \mathrm{~m}$ and $151-200 \mathrm{~m}$ was adopted as opined by Chalmers et al (2009) in analysing the impact power line on the rents of residential properties.

\section{Result and Discussion}

Response rates of $56.8 \%$ and $76.19 \%$ were achieved for Surulere area and registered Estate Surveying firms and in a bid to further understand powerlines, an indepth interview with the Managers and field officers of the Akangba PHCN sub station was conducted for the purpose of this research. In all, the survey recorded an average response rate of $66.5 \%$ and collated data was analysed using analytical statistics.

The result of the multivariate ANOVA analysis to determine the impact of HVOTLs on residential properties in Surulere is as shown in Table 1. 
Table 1 Surulere ANOVA Multivariate Analysis Using Distance Variables

Tests of Between-Subjects Effects

\begin{tabular}{|c|c|c|c|c|c|c|}
\hline Source & Dependent Variable & $\begin{array}{l}\text { Type III Sum } \\
\text { of Squares }\end{array}$ & $\begin{array}{l}\text { Mean } \\
\text { Square }\end{array}$ & $\mathbf{F}$ & Sig. & $\begin{array}{l}\text { Partial } \\
\text { Eta } \\
\text { Squared }\end{array}$ \\
\hline \multirow[t]{9}{*}{ Corrected Model } & Annual Rent & 14.999(a) & 5.000 & 3.896 & .010 & .053 \\
\hline & Erection of Pylon & $.000(\mathrm{~b})$ & .000 & &. & \\
\hline & Low Rent & $1.666(\mathrm{c})$ & .555 & 2.822 & .040 & .039 \\
\hline & Working Place Proximity & $.848(\mathrm{~d})$ & .283 & 1.274 & .284 & .018 \\
\hline & Cheap Land Value & $.225(\mathrm{e})$ & .075 & .407 & .748 & .006 \\
\hline & $\begin{array}{lcc}\text { Power line } & \text { affects } \\
\text { Property Demand } & \\
\end{array}$ & $2.250(\mathrm{f})$ & .750 & 1.705 & .167 & .024 \\
\hline & Radiation to Health & $.951(\mathrm{~g})$ & .317 & .700 & .553 & .010 \\
\hline & Humming and Buzzing & $2.551(\mathrm{~h})$ & .850 & 1.797 & .149 & .025 \\
\hline & $\begin{array}{l}\begin{array}{l}\text { Difficulty in Sales of } \\
\text { Properties }\end{array} \\
\end{array}$ & 4.850(i) & 1.617 & 3.297 & .021 & .045 \\
\hline \multirow{9}{*}{$\begin{array}{l}\text { Distance of House } \\
\text { from Power line }\end{array}$} & Annual Rent & 14.999 & 5.000 & 3.896 & .010 & .053 \\
\hline & Erection of Pylon & .000 & .000 & 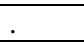 &. & \\
\hline & Low Rent & 1.666 & .555 & 2.822 & .040 & .039 \\
\hline & Working Place Proximity & .848 & .283 & 1.274 & .284 & .018 \\
\hline & Cheap Land Value & .225 & .075 & .407 & .748 & .006 \\
\hline & $\begin{array}{l}\text { Power line affects } \\
\text { Property Demand }\end{array}$ & 2.250 & .750 & 1.705 & .167 & .024 \\
\hline & Radiation to Health & .951 & .317 & .700 & .553 & .010 \\
\hline & Humming and Buzzing & 2.551 & .850 & 1.797 & .149 & .025 \\
\hline & $\begin{array}{l}\text { Difficulty in Sales of } \\
\text { Properties }\end{array}$ & 4.850 & 1.617 & 3.297 & .021 & .045 \\
\hline
\end{tabular}

From Table 1, the variables that were significatly influenced by the proximity to the power line were Annual Rents $(\mathrm{F}=3.90, \mathrm{P}=$ 0.010), Difficulty in Sales of Properties $(\mathrm{F}=3.30$, $\mathrm{P}=0.045)$ and Low Rent $(\mathrm{F}=2.82, \mathrm{P}=0.04)$. Annual Rent of residents was most significant at 0.010 accounting for 5.3\%, Difficulty in Sales of Properties constituted $4.5 \%$ while Low Rents constituted $4 \%$ in impact averaging the partial eta squared showed an impact of $2.75 \%$ on the rental values of residential properties within $200 \mathrm{~m}$ due to the power line in Surulere.

An examination of the means in Table 2 shows that the Annual Rent of houses within 105$150 \mathrm{~m}$ proximity commanded the highest rental value. This was followed by residents within the distance bracket of $51-100 \mathrm{~m}$. This must have been due to the accessibility fostered by the Aguda/Ijesa road, feeding the Ijesa Bus stop along the ApapaOworonshoki expressway and the new Okota link Bridge over the same expressway. This was the same fate as the arterial Itire road as it fed the Apapa-Oworonshoki expressway. Babs
Animashaun road parallel to the power line fed the ever busy Lagos Badagry expressway, making a " $T$ " junction with it. Also noted was the high rate of commercial activities along the roads parallel to the power lines. This characterisation fostered the cut out of large number of shops from the fence of residential properties directly adjacent the power line. Next in line were the residences within the 151-200m region. A 151-200meter distance crow flight from the Akangba transmission sub station fell within the Adeniran Ogunsanya road which was flooded as at the time of the study. It was also observed that many residences within this region were disserted as many suffered settlement under soil differentiation while some had being bought over for reconstruction.

Lastly, residences within $0-50 \mathrm{~m}$ suffered most in every respect especially in rental values as rent was least in this region. Especially for houses constructed with the ROWs reducing it in some cases to a bare 1meter, the fear of illegality threatened occupation of such houses. Also, the fear of falling wires constituted the greatest problem to the residents along HVOTL axis as respondents rated the same as having a high 
impact. The next three significant risk elements were the buzzing and humming noise of from the HVOTL, property stimatization and exposure to electrical radiation such that both recorded.

In summary, results of the ANOVA analysis from Surlere respondents ascertained the existence of an impact on rents payable for residential properties in Surulere with a mean value impact of $.=\mathrm{N}=786$ on rents payable within the power line neighbourhood. Also, the rents payable for residential property were found to increase with distances away from the HVOTL and with an average rental value appreciation of $=\mathrm{N}=5,000.00$ in the power line neighbourhood.

Table 2: Post Hoc Tests Distance of Residents from Power line.Multiple Comparisons

\begin{tabular}{|c|c|c|c|c|c|c|c|}
\hline \multirow[t]{3}{*}{$\begin{array}{l}\text { Dependent } \\
\text { Variable }\end{array}$} & $\begin{array}{c}\text { (I) } \\
\text { Distance of } \\
\text { House } \\
\text { from Power } \\
\quad \text { line }\end{array}$ & \begin{tabular}{|c}
$(\mathrm{J})$ \\
Distance of \\
House \\
from Power line
\end{tabular} & $\begin{array}{c}\text { Mean } \\
\text { Difference } \\
\text { (I-J) }\end{array}$ & $\begin{array}{l}\text { Std. } \\
\text { Error }\end{array}$ & Sig. & \multicolumn{2}{|c|}{$\begin{array}{c}95 \% \\
\text { Confidence Interva }\end{array}$} \\
\hline & & & Lower & Upper & Lower & Upper & Lower \\
\hline & & & Bound & Bound & Bound & Bound & Bound \\
\hline \multirow[t]{12}{*}{ Annual Rent } & $0-50 \mathrm{~m}$ & $51-100 \mathrm{~m}$ & -.2045 & .23501 & 1.000 & -.8305 & .4214 \\
\hline & & $101-150 \mathrm{~m}$ & $-.8000(*)$ & .28003 & .028 & -1.5459 & -.0541 \\
\hline & & $151-200 \mathrm{~m}$ & -.0348 & .26821 & 1.000 & -.7492 & .6796 \\
\hline & $51-100 \mathrm{~m}$ & $0-50 \mathrm{~m}$ & .2045 & .23501 & 1.000 & -.4214 & .8305 \\
\hline & & $101-150 \mathrm{~m}$ & $-.5955\left(^{*}\right)$ & .21932 & .043 & -1.1797 & -.0113 \\
\hline & & $151-200 \mathrm{~m}$ & .1697 & .20401 & 1.000 & -.3737 & .7131 \\
\hline & $101-150 \mathrm{~m}$ & $0-50 \mathrm{~m}$ & $.8000\left(^{*}\right)$ & .28003 & .028 & .0541 & 1.5459 \\
\hline & & $51-100 \mathrm{~m}$ & $.5955(*)$ & .21932 & .043 & .0113 & 1.1797 \\
\hline & & $151-200 \mathrm{~m}$ & $.7652(*)$ & .25457 & .018 & .0871 & 1.4432 \\
\hline & $151-200 \mathrm{~m}$ & $0-50 \mathrm{~m}$ & .0348 & .26821 & 1.000 & -.6796 & .7492 \\
\hline & & $51-100 \mathrm{~m}$ & -.1697 & .20401 & 1.000 & -.7131 & .3737 \\
\hline & & $101-150 \mathrm{~m}$ & $-.7652(*)$ & .25457 & .018 & -1.4432 & -.0871 \\
\hline \multirow[t]{12}{*}{ Low Rent } & $0-50 \mathrm{~m}$ & $51-100 \mathrm{~m}$ & -.2304 & .09204 & .078 & -.4756 & .0147 \\
\hline & & $101-150 \mathrm{~m}$ & -.2167 & .10967 & .297 & -.5088 & .0754 \\
\hline & & $151-200 \mathrm{~m}$ & $-.2924(*)$ & .10504 & .035 & -.5722 & -.0126 \\
\hline & $51-100 \mathrm{~m}$ & $0-50 \mathrm{~m}$ & .2304 & .09204 & .078 & -.0147 & .4756 \\
\hline & & $101-150 \mathrm{~m}$ & .0138 & .08589 & 1.000 & -.2150 & .2425 \\
\hline & & $151-200 \mathrm{~m}$ & -.0620 & .07990 & 1.000 & -.2748 & .1508 \\
\hline & $101-150 \mathrm{~m}$ & $0-50 \mathrm{~m}$ & .2167 & 10967 & .297 & -.0754 & .5088 \\
\hline & & $51-100 m$ & -.0138 & .08589 & 1.000 & -.2425 & .2150 \\
\hline & & $151-200 \mathrm{~m}$ & -.0758 & .09970 & 1.000 & -.3413 & .1898 \\
\hline & $151-200 \mathrm{~m}$ & $0-50 \mathrm{~m}$ & $.2924(*)$ & .10504 & .035 & .0126 & .5722 \\
\hline & & $51-100 \mathrm{~m}$ & .0620 & .07990 & 1.000 & -.1508 & .2748 \\
\hline & & $101-150 \mathrm{~m}$ & .0758 & .09970 & 1.000 & -.1898 & .3413 \\
\hline
\end{tabular}




\section{Conclusion}

This study has documented the impact of HVOTLs in prime locations within the metropolis of Lagos. The study has also established the existence of negative correlation between HVOTL and the rental values of residential property values within these areas.

Finally, it is hoped that the findings contained in this research work will be of particular interest to the academic community, Power Holding Company of Nigeria (PHCN), Estate Surveyors and Valuers and potential investors in the Nigerian real estate market residing in the diaspora.

\section{Recommendations}

The study recommends that the Federal Government of Nigeria utilise more creative alternative channels of bulk electric energy transfer. Though HVOTLs appear to be the cheapest option, redesigning pylons into more environmentally appealing forms may further reduce the impact of its imposing nature on the built and natural environment. Furthermore, insulation of overhead cables could further reduce electrical accidents should cables snap off the hanger or where insulation is absent, the use of trouble shooters in the form of monitors and controls in all transmitting and receiving power sub stations, capable of stopping the flow of current into snapped cables must be put in place in order to abate the possible electrocution of nearby residents and pedestrians as have been recorded in the country.

Sub-surface mode of electricity transfer via armour cables should be encouraged as it obtains in the petroleum industry where buried pipelines are employed in transfering oil products from on part of the country to the other.

Effective periodic maintenance should be carried out by the PHCN on HVOTLs with a view of replacing them with insulated wires (as used in the UK) conveyed by humanoid pylons. Also, the emforcement of the ROWs throughout the State must be implemented forcefully. ROWs would aid effective monitoring which in turn would keep vandals at bay and promote safety consciousness in residents living at proximal distances.

Lastly, the Nigerian Institution of Estate Surveyors and Valuers (NIESV) should fund research efforts into new valuation techniques for measuring the impact of environmental disamenties like high voltage overhead transmission lines (HVOTLs) on the values of various property.

\section{References}

About Lagos [Online] Available: Retrieved from http://www.aliciapublishers.com/Apatira

aboutlagos.htm (July, 2010)

Alexander, D. (1993). Natural Disasters. London: University of College London Press.

Chalmers, J.A. and Voorvaart, F.A. (2009). HighVoltage Transmission Lines: Proximity, Visibility and Encumbrance Effects, The Appraisal Journal, (Summer ed.), 227-45.

Colwell, P.F. (1990). Power Lines and Land Value, Journal of Real Estate Research, 5(1), 117- 27.

Colwell, P.F. and Foley, K.W. (1979). Electric Transmission Lines and the Selling Price of Residential Property, The Appraisal Journal, 47(4), 490-99.

Cowger, J.R, Bottlemillar S.C., MAI and James M. Cahill (1996). Transmission Line Impact on Residential Property, Right of Way.

Deyle, R. E., French, S. P., Olshanky, R. B., and Paterson, R. G. (1998). Hazard Assessment: A Factual Basis for Planning and Mitigation. (In R. J. Burby (Ed.), Cooperating with Nature: Confronting Natural Hazards with Land-Use Planning for Sustainable Communities, (pp. 119166). Washington, DC: Joseph Henry Press. Alexander.)

Esubiyi, A.O. (1994). 'Obsolescence and property values. A case study of Lagos', Unpublished B.Sc thesis, Obafemi Awolowo University, Ile-Ife, Nigeria.

Hamilton, S.W. and Carruthers, C. (1993). The Effects of Transmission Lines on Property Values in Residential Areas. University of British Columbia, Vancouver, B.C.

Hamilton, S.W. and Schwann, G.M. (1995). Do High Voltage Electric transmission Lines affect Property Value? Land Economics. 71(4), 436-44

Kinnard, W.H. Jr., (1967). Tower Power lines and Residential Property Values, The Appraisal Journal, 35, 269-284.

Lagos State History [Online] Available: Retrieved from http://en.wikipedia.org/wiki/File: LGA_Lagos.png (July, 2010) 
Microsoft Encarta ( 2008. C C 1993-2007 Microsoft corporation

NIESV (2009). Directory of Estate Surveyors and Valuers, The Nigerian Institution of Estate Surveyors and Valuer.

Nigeria's 2006_Population Census Arranged by State (Wikipedia) Retrieved from http://en.wikipedia.org/wiki/List_of_Nigerian_stat es_by_population (July, 2010).

Rosier, F.D. (1998). The Impact of High Voltage Power lines on Housing Prices. A Paper presented at the American Real Estate Conference Monterey California. April 15-18. Cited in Bond and Hopkins (2000).

Sandra Yin (2007) "Objections Surface Over Nigerian Census Results" [Online]. Available: Retrieved from at http://www.prb.org/Articles/2007/ObjectionsOver NigerianCensus .aspx

Savitz, D., Wachtel, H., Barnes, F., John, E., and Tvrdik, J. (1988) Case Control Study of Childhood Cancer and Exposure to $60 \mathrm{~Hz}$ Magnetic Fields, American Journal of Epidemiology, 128(1), 21-38.
Slovic, P. (1992). Perceptions of Risk: Reflections on the psychometric paradigm. In: Social Theories of Risk, S. Krimsky, D.Golding (eds) Preager, Westport, Connecticut, 117-152.

Surulere Local Government Area [Online] Available: Retrieved from http:// www.lagosstate.gov/Surulere_Local_Government Area (Lagos State Official website, 2009).

Syms, P. (1996). Perceptions of Risk in the Appraisal of Contaminated Real Estate Paper presented at RICS Cutting Edge. Estates Gazette, 26th Oct 1996. Issue 9643,146-148

Syms, P. (2001). The Effect of Public Perception on Property Values in Close Proximity to Electricity Distribution Equipment. RICS Foundation Cutting Edge 2001, Oxford Center for Real Estate Management, Oxford Brookes University, Headington.

Wertheimer, N. and Leeper, E. (1979) Electrical Wiring Configurations and Childhood Leukemia in Rode Island, American Journal of Epidemiology, 109, 273-284.

Wolverton, M. L. and Bottemiller, S.C. (2003) Further Analysis of Transmission Line Impact on Residential Property Values, The Appraisal Journal, (July ed.), 244-252. 